\title{
Metabolism of Tolclofos-methyl in Rats and Mice
}

\author{
Kazumasa Minara, Hideo Ohkawa and Junshi Miyamoto \\ Research Department, Pesticides Division, Sumitomo Chemical Co., Ltd., \\ Takarazuka, Hyogo 665, Japan
}

(Received September 5, 1980)

\begin{abstract}
On single oral administration of $5 \mathrm{mg} / \mathrm{kg}$ of ${ }^{14} \mathrm{C}$-tolclofos-methyl [Rizolex ${ }^{\circledR}, O, O$-dimethyl $O$-(2,6-dichloro-4-methylphenyl)phosphorothioate] labeled at the 4-methyl group to both sexes of rats and mice, approximately 87 to $91 \%$ of the radiocarbon administered was excreted into the urine and feces within 1 week. The total ${ }^{14} \mathrm{C}$-residue in the animal bodies 1 week after administration was less than $1 \%$ of the dose. The results of tissue analysis showed very low ${ }^{14} \mathrm{C}$-residue in the tissues, although a somewhat higher amount was found in the hair. More than 14 metabolites were detected in the excreta of both animal species. Of these, 13 metabolites were found in common in both rats and mice. The amounts of these metabolites differed between rats and mice, although no significant differences were found between male and female in either animal species. In both animals, tolclofos-methyl was mainly metabolized via oxidative desulfuration of the $P=S$ group to $P=O$ group, oxidation at the 4-methyl group and cleavage of the $P-O$-aryl and $P-O$-methyl linkages. The main metabolite was 3,5-dichloro-4-hydroxybenzoic acid, which was excreted as free form in rats, but further conjugated with glycine in mice.
\end{abstract}

\section{INTRODUCTION}

Tolclofos-methyl, Rizolex ${ }^{\circledR},[O, O$-dimethyl $O$ - (2, 6-dichloro-4-methylphenyl) phosphorothioate], is effective for control of soil borne diseases caused by Rhizoctonia solani and Corticium rolfsii, ${ }^{1)}$ and is now under development as an agricultural fungicide. The acute toxicity of this compound to mammals is very low, the oral $\mathrm{LD}_{50}$ for rats being ca. $5,000 \mathrm{mg} / \mathrm{kg}^{2}{ }^{2)} \quad$ This compound is found to vaporize easily from water solution and soil surface. Moreover, on exposure to sunlight, it is rapidly decomposed to 2,6-dichloro-4methylphenol and 3,5-dichloro-4-hydroxybenzoic acid in air and water, ${ }^{3)}$ and on surfaces of soils and plants. ${ }^{4)}$ The present paper deals with the metabolism of tolclofos-methyl in rats and mice.

\section{MATERIALS AND METHODS}

\section{Chemicals}

${ }^{14} \mathrm{C}$-Tolclofos-methyl labeled at the 4 methyl group was prepared by Yoshitake et $a l .^{5)}$ of the Institute for Biological Science, Sumitomo Chemical Co., Ltd., Takarazuka,
Hyogo, Japan. The preparation had a specific activity of $16.2 \mathrm{mCi} / \mathrm{mmole}$ and radiochemical purity of more than $99 \%$, as determined by radio-thin layer chromatography in solvent systems of $n$-hexane/ether $(5: 1$, $\mathrm{v} / \mathrm{v}), \quad n$-hexane/acetone $(4: 1, \mathrm{v} / \mathrm{v})$, benzene and chloroform. Non-radioactive tolclofosmethyl (TM) and the following compounds were synthesized in the Research Department, Pesticide Division, Sumitomo Chemical Co., Ltd. 2,6-Dichloro-4-methylphenol $\left(\mathrm{Ph}-\mathrm{CH}_{3}\right)$ and 3,5-dichloro-4-hydroxybenzaldehyde $(\mathrm{Ph}-\mathrm{CHO})$ were prepared by chlorination of $p$-cresol and 4-hydroxybenzaldehyde, respectively, according to Biltz. ${ }^{6}{ }^{\prime} \quad O, O-\mathrm{Di}-$ methyl $O$-(2,6-dichloro-4-formylphenyl)phosphorothioate (TM-CHO) was prepared as follows: To a mixture of 3,5-dichloro-4hydroxybenzaldehyde $(1.9 \mathrm{~g}), \mathrm{CuCl}(1 \mathrm{~g})$ and $\mathrm{K}_{2} \mathrm{CO}_{3}(1.4 \mathrm{~g})$ in $20 \mathrm{ml}$ of toluene, $1.6 \mathrm{~g}$ of O,O-dimethyl phosphorothioate was added dropwise at room temperature over $0.5 \mathrm{hr}$. Then the reaction mixture was further stirred for $3 \mathrm{hr}$ at 60 to $80^{\circ} \mathrm{C}^{7)}$ After cooling the mixture, water was added to dissolve the precipitated inorganic compounds, and the 
toluene solution was washed with water and dried over anhydrous sodium sulfate. After distilling off toluene in vacuo, $2 \mathrm{~g}$ of the crude product was obtained and purified on a silica gel column using benzene as the eluting solvent. $O, O$-Dimethyl $O-(2,6$-dichloro-4formyl-phenyl)phosphate (TM-CHO) was prepared as follows: $\left.{ }^{8}\right)$ To a stirring mixture of dimethylphosphite $(5.5 \mathrm{~g})$ and $\mathrm{Ph}-\mathrm{CHO}(9.5$ g) in $10 \mathrm{ml}$ of carbon tetrachloride cooled to $5^{\circ} \mathrm{C}, 8.4 \mathrm{ml}$ of triethylamine was added dropwise. The reaction mixture was stirred at room temperature for $3 \mathrm{hr}$ and then filtered off. The filtrate was washed with water and dried over anhydrous sodium sulfate. After concentration, $11 \mathrm{~g}$ of the crude product was obtained and purified on a silica gel column eluted with a $2: 9$ mixture of benzene and ether. $O, O$-Dimethyl $O-(2,6$-dichloro-4methylphenyl)phosphate (TMO) was also prepared from dimethylphosphite and $\mathrm{Ph}-\mathrm{CH}_{3}$ in the same manner as with TM-CHO. 3,5Dichloro-4-hydroxybenzyl alcohol $\left(\mathrm{Ph}-\mathrm{CH}_{2}\right.$ $\mathrm{OH})$ was prepared as follows: To $1.9 \mathrm{~g}$ of $\mathrm{Ph}-\mathrm{CHO}$ in $20 \mathrm{ml}$ of methanol, $2 \mathrm{~g}$ of $\mathrm{NaBH}_{4}$ was added slowly at $0^{\circ} \mathrm{C}$ by stirring. ${ }^{9}$ The mixture was stirred at $5^{\circ} \mathrm{C}$ for $30 \mathrm{~min}$. Then water was added to the mixture, which was extracted with benzene. The benzene layer was dried over anhydrous sodium sulfate. After concentration of the benzene solution, the crude $\mathrm{Ph}-\mathrm{CH}_{2} \mathrm{OH}$ was obtained, and purified by column chromatography using silica gel and benzene saturated with formic acid as the solvent. Similarly, $O, O$-dimethyl $O$ (2, 6-dichloro-4-hydroxymethylphenyl) phosphorothioate $\left(\mathrm{TM}-\mathrm{CH}_{2} \mathrm{OH}\right)$ and $\mathrm{O}, O$-dimethyl $O$ - (2, 6-dichloro - 4-hydroxymethylphenyl)phosphate (TMO- $\mathrm{CH}_{2} \mathrm{OH}$ ) were prepared from the corresponding aldehydes. O,O-Dimethyl $O-(2,6$-dichloro-4-carboxyphenyl) phosphorothioate $(\mathrm{TM}-\mathrm{COOH})$ was prepared as follows: To $3.15 \mathrm{~g}$ of $\mathrm{TM}-\mathrm{CHO}$ in $5 \mathrm{ml}$ of methanol, $4 \mathrm{~g}$ of potassium permanganate dissolved in $10 \mathrm{ml}$ of water was added dropwise at room temperature by stirring. ${ }^{10)}$ After an additional $1 \mathrm{hr}$ of stirring, the reaction mixture was adjusted to $\mathrm{pH} 1$ with $1 \mathrm{~N} \mathrm{HCl}$ solution, and extracted with $30 \mathrm{ml}$ of ether. The ether layer was dried over anhydrous sodium sulfate. After evaporation of the solvent in vacuo, the crude $\mathrm{TM}-\mathrm{COOH}$ was obtained and purified by silica gel column chromatography using benzene saturated with formic acid as the solvent. Similarly, $O, O$-dimethyl $O-(2,6-$ dichloro-4-carboxyphenyl) phosphate (TMO$\mathrm{COOH})$ was prepared from the corresponding aldehyde. $O$-Methyl $O$-hydrogen $O$-(2,6-dichloro-4-methylphenyl)phosphorothioate(DMTM), $O$-methyl $O$-hydrogen $O-(2,6-$ dichloro4-methylphenyl)phosphate (DM-TMO), $O$ methyl $O$-hydrogen $O$ - (2, 6-dichloro-4-hydroxymethylphenyl) phosphorothioate (DMTM- $\left.\mathrm{CH}_{2} \mathrm{OH}\right), \quad O$-methyl-O-hydrogen $O-(2,6-$ dichloro - 4 - hydroxymethylphenyl) phosphate (DM-TMO- $\mathrm{CH}_{2} \mathrm{OH}$ ), $O$-meythyl $O$-hydrogen $O$-(2, 6-dichloro-4-carboxyphenyl) phosphorothioate (DM-TM-COOH) and $O-$ methyl $O-$ hydrogen $O$-(2,6-dichloro-4-carboxyphenyl)phosphate (DM-TMO-COOH) were prepared from TM, TMO, TM- $-\mathrm{CH}_{2} \mathrm{OH}$, TMO- $\mathrm{CH}_{2} \mathrm{OH}, \mathrm{TM}-$ $\mathrm{COOH}$, respectively, by reaction with 1.2 -fold moles of potassium dimethyldithiocarbamate in methanol at room temperature for $5 \mathrm{hr}^{1{ }^{11}}$ Each crude product was purified by repeated thin-layer chromatography $(t l c)$ in toluene/ ethyl acetate/isopropanol/acetic acid (8:12: $5: 3, \mathrm{v} / \mathrm{v})$. The structure of these compounds was confirmed by nuclear magnetic resonance (NMR) spectrometry (Hitachi R$40 \mathrm{~B}, 90 \mathrm{MHz}$, or JEOL-JNM-FX-100, 100 $\mathrm{MHz}$ ) and/or mass (MS) spectrometry (Shimadzu LKB-9000, $70 \mathrm{eV}$ ). Data on NMR and MS spectra of the authentic compounds are listed in Table 1 and 2 , respectively. $p$ Cresol, 4-hydroxybenzaldehyde and 3,5-dichloro-4-hydroxybenzoic acid $(\mathrm{Ph}-\mathrm{COOH})$ were purchased from Aldrich Co., Milwaukee, Wis.

\section{Analysis}

Precoated silica gel chromatoplates (silica gel $60 \mathrm{~F}_{254}, 0.25 \mathrm{~mm}$ thickness, E. Merck) were used for both analytical and preparative tlc. $R f$ values for major metabolites and solvent systems used are listed in Table 3 . Radioactive regions on the developed $t l c$ plates were detected by radioautography using industrial X-ray films (IX-50, Fuji Photo Film Co., Ltd., Tokyo), and spots of unlabeled reference compounds were visualized under ultraviolet light irradiation. 
Table 1 NMR spectra of tolclofos-methyl and reference compounds.

\begin{tabular}{|c|c|c|}
\hline Compound & Solvent & Spectral signal $\left(90 \mathrm{MHz}, \delta^{\mathrm{TMS}} \mathrm{ppm}\right)$ \\
\hline $\mathrm{TM}$ & $\mathrm{CDCl}_{3}$ & $\begin{array}{l}2.29 \text { (methyl, } 3 \mathrm{H}, \mathrm{s}), 3.93 \text { (methoxy, } 6 \mathrm{H}, \mathrm{d}, J_{0}=14 \mathrm{~Hz} \text { ), } \\
7.15 \text { (aromatic, } 2 \mathrm{H}, \mathrm{s})\end{array}$ \\
\hline $\mathrm{TM}-\mathrm{CH}_{2} \mathrm{OH}$ & $\mathrm{CDCl}_{3}$ & $\begin{array}{l}3.96\left(\text { methoxy, } 6 \mathrm{H}, \mathrm{d}, J_{0}=14 \mathrm{~Hz}\right), 4.63 \text { (hydroxymethyl, } 2 \mathrm{H}, \mathrm{s} \text { ), } \\
7.37 \text { (aromatic, } 2 \mathrm{H}, \mathrm{s})\end{array}$ \\
\hline TM-COOH & $\left(\mathrm{CD}_{3}\right)_{2} \mathrm{CO}$ & $3.99\left(\right.$ methoxy, $\left.6 \mathrm{H}, \mathrm{d}, J_{0}=14 \mathrm{~Hz}\right), 8.07$ (aromatic, $\left.2 \mathrm{H}, \mathrm{s}\right)$ \\
\hline TMO & $\mathrm{CDCl}_{3}$ & $\begin{array}{l}2.30 \text { (methyl, } 3 \mathrm{H}, \mathrm{s}), 3.97 \text { (methoxy, } 6 \mathrm{H}, \mathrm{d}, J_{0}=12 \mathrm{~Hz} \text { ) } \\
7.17 \text { (aromatic, } 2 \mathrm{H}, \mathrm{s})\end{array}$ \\
\hline TMO- $\mathrm{CH}_{2} \mathrm{OH}$ & $\mathrm{CDCl}_{3}$ & $\begin{array}{l}3.95 \text { (methoxy, } 6 \mathrm{H}, \mathrm{d}, J_{0}=12 \mathrm{~Hz} \text { ), } 4.62 \text { (hydroxymethyl, } 2 \mathrm{H}, \mathrm{s} \text { ), } \\
7.45 \text { (aromatic, } 2 \mathrm{H}, \mathrm{s} \text { ) }\end{array}$ \\
\hline TMO-COOH & $\left(\mathrm{CD}_{3}\right)_{2} \mathrm{CO}$ & $4.00\left(\right.$ methoxy, $\left.6 \mathrm{H}, \mathrm{d}, J_{0}=12 \mathrm{~Hz}\right), 8.07$ (aromatic, $\left.2 \mathrm{H}, \mathrm{s}\right)$ \\
\hline $\mathrm{Ph}-\mathrm{CH}_{3}$ & $\mathrm{CDCl}_{3}$ & 2.20 (methyl, 3H, s), 7.00 (aromatic, $2 \mathrm{H}, \mathrm{s}$ ) \\
\hline $\mathrm{Ph}-\mathrm{CH}_{2} \mathrm{OH}$ & $\left(\mathrm{CD}_{3}\right)_{2} \mathrm{CO}$ & 4.57 (hydroxymethyl, 2H, s), 7.35 (aromatic, 2H, s) \\
\hline $\mathrm{Ph}-\mathrm{COOH}$ & $\left(\mathrm{CD}_{3}\right)_{2} \mathrm{CO}$ & 7.96 (aromatic, $2 \mathrm{H}, \mathrm{s}$ ) \\
\hline DM-TM & $\mathrm{CD}_{3} \mathrm{OD}$ & $\begin{array}{l}2.27 \text { (methyl, } 3 \mathrm{H}, \mathrm{s}), 3.81 \text { (methoxy, } 3 \mathrm{H}, \mathrm{d}, J_{0}=14 \mathrm{~Hz} \text { ), } \\
7.15 \text { (aromatic, } 2 \mathrm{H}, \mathrm{s} \text { ) }\end{array}$ \\
\hline DM-TM- $\mathrm{CH}_{2} \mathrm{OH}$ & $\mathrm{CD}_{3} \mathrm{OD}$ & $\begin{array}{l}3.75 \text { (methoxy, } 3 \mathrm{H}, \mathrm{d}, J_{0}=14 \mathrm{~Hz} \text { ), } 4.48 \text { (hydroxymethyl, } 2 \mathrm{H}, \mathrm{s} \text { ), } \\
7.23 \text { (aromatic, } 2 \mathrm{H}, \mathrm{s} \text { ) }\end{array}$ \\
\hline $\mathrm{DM}-\mathrm{TM}-\mathrm{COOH}$ & $\mathrm{CD}_{3} \mathrm{OD}$ & $3.76\left(\right.$ methoxy, $\left.3 \mathrm{H}, \mathrm{d}, J_{0}=14 \mathrm{~Hz}\right), 7.80$ (aromatic, $\left.2 \mathrm{H}, \mathrm{s}\right)$ \\
\hline DM-TMO & $\mathrm{CD}_{3} \mathrm{OD}$ & $\begin{array}{l}2.26 \text { (methyl, } 3 \mathrm{H}, \mathrm{s}), 3.76 \text { (methoxy, } 3 \mathrm{H}, \mathrm{d}, J_{0}=12 \mathrm{~Hz} \text { ), } \\
7.18 \text { (aromatic, } 2 \mathrm{H}, \mathrm{s})\end{array}$ \\
\hline DM-TMO- $\mathrm{CH}_{2} \mathrm{OH}$ & $\mathrm{CD}_{3} \mathrm{OD}$ & $\begin{array}{l}3.74 \text { (methoxy, } 3 \mathrm{H}, \mathrm{d}, J_{0}=12 \mathrm{~Hz} \text { ), } 4.48 \text { (hydroxymethyl, } 2 \mathrm{H}, \mathrm{s} \text { ), } \\
7.25 \text { (aromatic, } 2 \mathrm{H}, \mathrm{s} \text { ) }\end{array}$ \\
\hline DM-TMO-COOH & $\mathrm{CD}_{3} \mathrm{OD}$ & $3.75\left(\right.$ methoxy, $\left.3 \mathrm{H}, \mathrm{d}, J_{0}=12 \mathrm{~Hz}\right), 7.83($ aromatic, $2 \mathrm{H}, \mathrm{s})$ \\
\hline $\mathrm{Ph}-\mathrm{CHO}$ & $\left(\mathrm{CD}_{3}\right)_{2} \mathrm{CO}$ & 7.93 (aromatic, 2H, s), 9.93 (formyl, $1 \mathrm{H}, \mathrm{s}$ ) \\
\hline $\mathrm{TM}-\mathrm{CHO}$ & $\mathrm{CDCl}_{3}$ & $\begin{array}{l}\left.3.99\left(\text { methoxy, } 6 \mathrm{H}, \mathrm{d}, J_{0}=14 \mathrm{~Hz}\right), 7.89 \text { (aromatic, } 2 \mathrm{H}, \mathrm{s}\right) \text {, } \\
9.93(\text { formyl, } 1 \mathrm{H}, \mathrm{s})\end{array}$ \\
\hline TMO-CHO & $\mathrm{CDCl}_{3}$ & $\begin{array}{l}\left.4.00\left(\text { methoxy, } 6 \mathrm{H}, \mathrm{d}, J_{u}=12 \mathrm{~Hz}\right), 7.89 \text { (aromatic, } 2 \mathrm{H}, \mathrm{s}\right) \\
9.93(\text { formyl, } 1 \mathrm{H}, \mathrm{s})\end{array}$ \\
\hline
\end{tabular}

Table 2 Mass spectra of tolclofos-methyl and reference compounds.

\begin{tabular}{ll}
\hline \multicolumn{1}{c}{ Compound } & \multicolumn{1}{c}{$m / e($ at $70 \mathrm{eV})$} \\
\hline $\mathrm{TM}$ & $267(\mathrm{M}+2-\mathrm{Cl}), 265(\mathrm{M}-\mathrm{Cl}), 175\left[\mathrm{OC}_{6} \mathrm{H}_{2} \mathrm{Cl}_{2} \mathrm{CH}_{3}\right], 125\left[\left(\mathrm{CH}_{3}\right)_{2} \mathrm{P}(\mathrm{S})\right]$ \\
$\mathrm{TM}-\mathrm{CH}_{2} \mathrm{OH}$ & $283(\mathrm{M}+2-\mathrm{Cl}), 281(\mathrm{M}-\mathrm{Cl}), 125\left[\left(\mathrm{CH}_{3}\right)_{2} \mathrm{P}(\mathrm{S})\right]$ \\
$\mathrm{TM}-\mathrm{COOH}$ & $297(\mathrm{M}+2-\mathrm{Cl}), 295(\mathrm{M}-\mathrm{Cl}), 205\left[\mathrm{OC}_{6} \mathrm{H}_{2} \mathrm{Cl}_{2} \mathrm{CH}_{3}\right], 125\left[\left(\mathrm{CH}_{3}\right)_{2}(\mathrm{~S})\right]$ \\
$\mathrm{TMO}$ & $288(\mathrm{M}+4), 286(\mathrm{M}+2), 284(\mathrm{M}), 215(\mathrm{M}+2-\mathrm{Cl}), 249(\mathrm{M}-\mathrm{Cl}), 234[\mathrm{M}-50(\mathrm{Cl}, \mathrm{CH} 3)]$, \\
& $109\left[\left(\mathrm{CH}_{3}\right)_{2} \mathrm{P}(\mathrm{O})\right]$ \\
$\mathrm{TMO}-\mathrm{CH}_{2} \mathrm{OH}$ & $267(\mathrm{M}+2-\mathrm{Cl}), 265(\mathrm{M}-\mathrm{Cl}), 109\left[\left(\mathrm{CH}_{3}\right)_{2} \mathrm{P}(\mathrm{O})\right]$ \\
$\mathrm{TMO}-\mathrm{COOH}$ & $281(\mathrm{M}+2-\mathrm{Cl}), 279(\mathrm{M}-\mathrm{Cl}), 109\left[\left(\mathrm{CH}_{3}\right)_{2} \mathrm{P}(\mathrm{O})\right]$ \\
$\mathrm{Ph}-\mathrm{CH} \mathrm{H}_{3}$ & $180(\mathrm{M}+4), 178(\mathrm{M}+2), 176(\mathrm{M}), 143(\mathrm{M}+2-\mathrm{Cl}), 141(\mathrm{M}-\mathrm{Cl})$ \\
$\mathrm{Ph}-\mathrm{CH}{ }_{2} \mathrm{OH}$ & $196(\mathrm{M}+4), 195(\mathrm{M}+3), 194(\mathrm{M}+2), 193(\mathrm{M}+1), 192(\mathrm{M}), 191(\mathrm{M}-\mathrm{Cl})$, \\
& $177(\mathrm{M}+2-\mathrm{OH}), 175(\mathrm{M}-\mathrm{OH}), 165(\mathrm{M}+2-\mathrm{Cl}), 163(\mathrm{M}-\mathrm{CHO}), 159(\mathrm{M}+2-\mathrm{Cl})$, \\
& $157(\mathrm{M}-\mathrm{Cl})$ \\
$\mathrm{Ph}-\mathrm{COOH}$ & $210(\mathrm{M}+4), 208(\mathrm{M}+2), 206(\mathrm{M}), 193(\mathrm{M}+4-\mathrm{OH}), 191(\mathrm{M}+2-\mathrm{OH}), 189(\mathrm{M}-\mathrm{OH})$ \\
$\mathrm{Ph}-\mathrm{CHO}$ & $194(\mathrm{M}+4), 193(\mathrm{M}+3), 192(\mathrm{M}+2), 191(\mathrm{M}+1), 190(\mathrm{M}), 189(\mathrm{M}-1)$, \\
& $163(\mathrm{M}+2-\mathrm{CHO}), 161(\mathrm{M}-\mathrm{CHO})$ \\
$\mathrm{TM}-\mathrm{CHO}$ & $281(\mathrm{M}+2-\mathrm{Cl}), 279(\mathrm{M}-\mathrm{Cl}), 125\left[\left(\mathrm{CH}_{3}\right)_{2} \mathrm{P}(\mathrm{S})\right]$ \\
$\mathrm{TMO}-\mathrm{CHO}$ & $302(\mathrm{M}+4), 300(\mathrm{M}+2), 298(\mathrm{M}), 265(\mathrm{M}+2-\mathrm{Cl}), 263(\mathrm{M}-\mathrm{Cl})$, \\
& $109\left[(\mathrm{CH})_{2} \mathrm{P}(\mathrm{O})\right]$
\end{tabular}


Table $3 R f$ values of tolclofos-methyl and its ${ }^{14} C$-metabolites in the urine and feces from rats and mice with six solvent systems in thin layer chromatography.

\begin{tabular}{|c|c|c|c|c|c|c|c|}
\hline & \multirow{2}{*}{ Metabolite } & \multicolumn{6}{|c|}{$R f$ in the solvent system* } \\
\hline & & A & $\mathrm{B}$ & $\mathrm{C}$ & $\mathrm{D}$ & $\mathrm{E}$ & $\mathrm{F}$ \\
\hline S 1 & TM & 0.66 & 0.73 & 0.84 & 0.75 & 0.69 & 0.58 \\
\hline S 2 & $\mathrm{Ph}-\mathrm{CH}_{3}$ & 0.58 & 0.75 & 0.82 & 0.69 & 0.70 & 0.47 \\
\hline S 3 & $\mathrm{TM}-\mathrm{CH}_{2} \mathrm{OH}$ & 0.38 & 0.73 & 0.73 & 0.69 & 0.49 & 0.33 \\
\hline S 4 & $\mathrm{Ph}-\mathrm{CH}_{2} \mathrm{OH}$ & 0.23 & 0.67 & 0.53 & 0.57 & 0.50 & 0.13 \\
\hline S 5 & $\mathrm{TM}-\mathrm{COOH}$ & 0.03 & 0.70 & 0.63 & 0.39 & 0.30 & 0.29 \\
\hline S 6 & $\mathrm{Ph}-\mathrm{COOH}$ & 0.05 & 0.69 & 0.55 & 0.33 & 0.40 & 0.26 \\
\hline S 7 & $\mathrm{TMO}-\mathrm{COOH}$ & 0.00 & 0.60 & 0.39 & 0.25 & 0.07 & 0.13 \\
\hline S 8 & $\mathrm{Ph}-\mathrm{CO}-$ glycine & 0.00 & 0.54 & 0.33 & 0.10 & & \\
\hline S 9 & $\mathrm{DM}-\mathrm{TM}$ & 0.00 & 0.45 & 0.25 & 0.21 & & 0.03 \\
\hline $\mathrm{S} 10$ & $\mathrm{DM}-\mathrm{TM}-\mathrm{COOH}$ & 0.00 & 0.37 & & 0.13 & & \\
\hline S11 & DM-TM- $\mathrm{CH}_{2} \mathrm{OH}$ & 0.00 & 0.35 & & 0.13 & & \\
\hline S12 & DM-TMO & 0.00 & 0.26 & 0.12 & 0.10 & & \\
\hline $\mathrm{S} 13$ & DM-TMO-COOD & 0.00 & 0.20 & & 0.00 & & \\
\hline S14 & $\mathrm{DM}-\mathrm{TMO}-\mathrm{CH}_{2} \mathrm{OH}$ & 0.00 & 0.10 & & 0.07 & & \\
\hline
\end{tabular}

* Solvent systems used; A: chloroform/acetone $(9: 1, \mathrm{v} / \mathrm{v}), \mathrm{B}:$ toluene/ethyl acetate/isopropanol/ acetic acid $(8: 12: 5: 3, \mathrm{v} / \mathrm{v}), \mathrm{C}:$ toluene/ethyl formate/formic acid $(5: 7: 1, \mathrm{v} / \mathrm{v})$, D: methanol/ chloroform $(1: 3, \mathrm{v} / \mathrm{v}), \mathrm{E}:$ benzene/ether $(2: 9, \mathrm{v} / \mathrm{v}), \mathrm{F}:$ toluene/acetic acid $(7: 1, \mathrm{v} / \mathrm{v})$.

Radioactivity in urine, organo-soluble extracts and silica gel regions scraped from $t l c$ plates was quantitated by liquid scintillation counting $(l s c)$ on a Packard Tri-Carb 3385 with automatic external standard, as reported previously. ${ }^{12}$ Counting efficiency and back ground levels were more than $85 \%$ and 40 to $50 \mathrm{cpm}$, respectively, in low potassium glass vials containing $15 \mathrm{ml}$ of a dioxane scintillation fluid ( $5 \mathrm{~g}$ of 2,5-diphenyl oxazole and $100 \mathrm{~g}$ of naphthalene in 1 liter of dioxane). Aliquots (0.2 to $0.6 \mathrm{~g})$ of feces, tissues and organo-insoluble residues were combusted with a sample oxidizer (Packard Tri-Carb 306) before $l s c$. For combustion analysis, a mixture of $15 \mathrm{ml}$ of ${ }^{14} \mathrm{CO}_{2}$-counting cocktail [OXIPREP $^{\mathrm{TM}-2}$, New England Nuclear (NEN), Boston] and $9 \mathrm{ml}$ of ${ }^{14} \mathrm{CO}_{2}$-absorber (OXISORB ${ }^{\mathrm{TM}}$ $\mathrm{CO}_{2}, \mathrm{NEN}$ ) was used. Counting efficiency and background levels were more than $73 \%$ and 45 to $55 \mathrm{cpm}$, respectively. Radioactivity in alkaline solution $(0.5 \mathrm{~N} \mathrm{NaOH})$ was quantitated by $l s c$ after neutralization with $0.5 \mathrm{~N}$ $\mathrm{HCl}$ solution and then mixing with $10 \mathrm{ml}$ of Aquasol $2^{\circledR}(\mathrm{NEN})$. In this case, counting efficiency and background levels were more than $83 \%$ and 45 to $55 \mathrm{cpm}$, respectively.

\section{Treatment of Animals}

Five-week old Sprague-Dawley rats weighing approximately $190 \mathrm{~g}$ (male) and $140 \mathrm{~g}$ (female) were supplied by Nihon Dobutsu Co., Osaka. Seven-week old ICR mice weighing $28 \mathrm{~g}$ (male) and $24 \mathrm{~g}$ (female) were purchased from Shizuoka Agricultural Cooperative Association for Laboratory Animals, Shizuoka. Rats and mice were placed in polycarbonate cages in an air-conditioned room of $24 \pm 2^{\circ} \mathrm{C}$ and allowed to adjust to the environment for 1 week before administration. The animals were supplied with a diet (CE-2 Clea Japan, Inc.) and water ad libitum during the experiment. Both rats and mice were individually treated with a single oral dose of $5 \mathrm{mg} / \mathrm{kg}$ of ${ }^{14} \mathrm{C}$-tolclofos-methyl suspended in $10 \mathrm{ml}$ of corn oil (Yamakei Sangyo, Osaka) by stomach intubation. The treated rats and mice were individually housed in metabolism cages (Metabolica CO-2 ${ }^{\circledR}$, Sugiyamagen Iriki Co., Ltd., Tokyo), which enabled separate collection of urine, feces and expired air. Radioactive carbon dioxide expired was trapped in 250 $\mathrm{ml}$ of $0.5 \mathrm{~N} \mathrm{NaOH}$ solution. During a sampling period, urine and feces were kept at 0 to $5{ }^{\circ} \mathrm{C}$ to prevent further alteration of metabolites. Seven days after administration, the 
treated rats were sacrificed, and tissues were dissected out and homogenized by a multiblender mill BL-3 (Nihon Seiki Co., Tokyo), aliquots $(0.2$ to $0.6 \mathrm{~g})$ of which were subjected to combustion analysis prior to $l s c$.

Whole-body autoradiography was conducted according to the methods of Ullberg ${ }^{13}$ 1,6 and $24 \mathrm{hr}$ after administration of $5 \mathrm{mg} /$ $\mathrm{kg}$ of the ${ }^{14} \mathrm{C}$-compound to male rats.

\section{Extraction, Analysis and Identification of Metabolites}

The one-day pooled urine from the treated rats or mice was adjusted to $\mathrm{pH} 1$ with $2 \mathrm{~N}$ $\mathrm{HCl}$ and then extracted 3 times with 3 -fold volumes of ethyl ether. The one-day pooled feces was homogenized in an equal volume of distilled water using a Waring blender. The homogenate was adjusted to $\mathrm{pH} 1$ and extracted 3 times with 3 -fold volumes of ethyl ether. The combined ethyl ether extracts from urine and feces were each concentrated, and the residues were dissolved in small volumes of methanol and subjected to onedimensional tlc cochromatography with authentic standards in solvent systems A), C), E) and F). After extraction, the remaining aqueous layers from urine and feces were each neutralized with $2 \mathrm{~N} \mathrm{NaOH}$ and then lyophilized. The residues were each suspended in a small volume of methanol, and subjected to one-dimensional $t l c$ cochromatography with authentic standards in solvent systems B) and D).

To obtain larger amounts of ${ }^{14} \mathrm{C}$-metabolites, ${ }^{14} \mathrm{C}$-tolclofos-methyl with specific activity of $1.62 \mathrm{mCi} / \mathrm{mmol}$ was orally administered to 30 male mice at the rate of $50 \mathrm{mg} / \mathrm{kg}$, and urine was collected during 1 day post-treatment. The collected urine $(46 \mathrm{ml})$ was subjected to column chromatography (column size; $185 \times 34 \mathrm{~mm} \phi$ ) on Amberite XAD-2 resin, and eluted with $270 \mathrm{ml}$ of water, followed by $150 \mathrm{ml}$ of methanol. The methanol fraction was concentrated in vacuo and the residue was subjected to preparative $t l c$ in solvent systems B) and D). The separated fractions on $t l c$ plates were each extracted with methanol and then subjected to tlc cochromatography and/or spectroanalysis $\left({ }^{1} \mathrm{H}-\right.$ Fourier transform-NMR, $100 \mathrm{MHz}$ and EI-MS, 70
$\mathrm{eV})$.

\section{RESULTS}

\section{Distribution and Tissue Residues of Radio- carbon}

After single oral administration of ${ }^{14} \mathrm{C}$ tolclofos-methyl to male rats at the rate of $5 \mathrm{mg} / \mathrm{kg}$, whole-body autoradiography was conducted at various time intervals. As shown in Fig. 1, the highest radioactivity was located in digestive organs including stomach and intestines $1 \mathrm{hr}$ and $6 \mathrm{hr}$ after treatment, followed by kidney and liver. Other tissues such as brain, spleen, eye-ball, testis, thymus, heart, lung, muscle, salivary gland, spinal cord and bone contained lower radioactivity. Twenty four hr after dosing, very low radio-

Table 4 Contents of total ${ }^{14} \mathrm{C}$ in tissues of male and female rats 7 days after oral administration of $5 \mathrm{mg} / \mathrm{kg}$ of tolclofosmethyl.

\begin{tabular}{|c|c|c|}
\hline \multirow[t]{2}{*}{ Tissues } & \multicolumn{2}{|c|}{$\begin{array}{l}\text { Total }{ }^{14} \mathrm{C} \text { (ng tolclofos- } \\
\text { methyl eq./g tissue) }\end{array}$} \\
\hline & male & female \\
\hline Plasma & 1 & 2 \\
\hline Red blood cell & 4 & 5 \\
\hline Brain & 1 & 1 \\
\hline Eye-ball & 1 & 3 \\
\hline Thyroid & $<1$ & $<1$ \\
\hline Thymus & 1 & 2 \\
\hline Lung & 2 & 3 \\
\hline Heart & 1 & 1 \\
\hline Kidney & 4 & 4 \\
\hline Liver & 4 & 5 \\
\hline Pancreas & 1 & 1 \\
\hline Spleen & 1 & 2 \\
\hline Adrenal & 3 & 4 \\
\hline Muscle & 1 & 2 \\
\hline Fat & 6 & 6 \\
\hline Spinal cord & 1 & 1 \\
\hline Sciatic nerve & 3 & 1 \\
\hline Skin & 6 & 6 \\
\hline Hair & 52 & 60 \\
\hline Testis & 1 & \\
\hline Ovary & & 4 \\
\hline Uterus & & 3 \\
\hline Stomach & 2 & 2 \\
\hline Duodenum & 2 & 2 \\
\hline Jejunum & 2 & 2 \\
\hline Caecum & 2 & 2 \\
\hline Colon and rectum & 3 & 3 \\
\hline
\end{tabular}




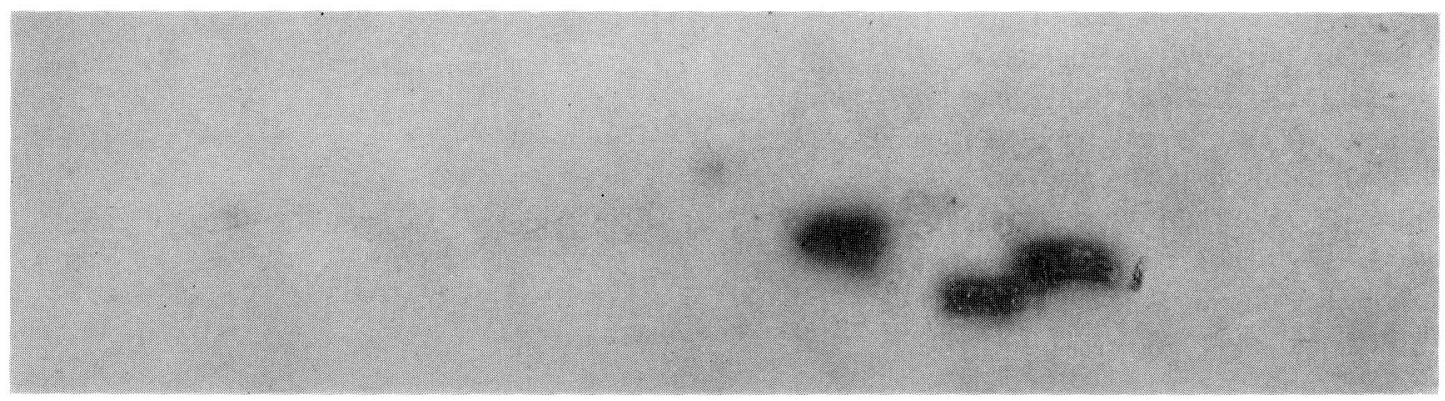

after $1 \mathrm{hr}$

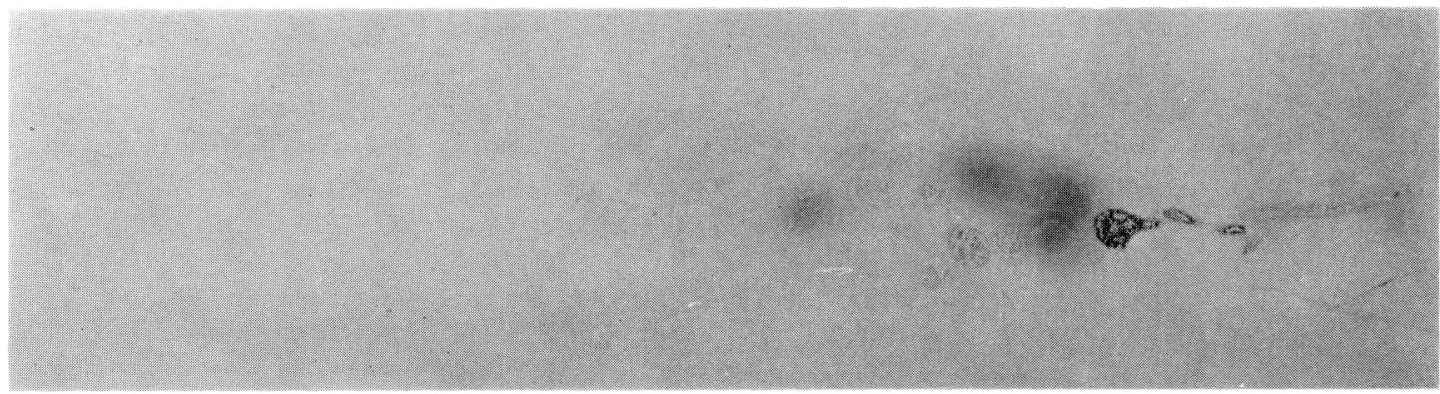

after $6 \mathrm{hr}$

after $24 \mathrm{hr}$

Fig. 1 Autoradiograms showing distribution of radioactivity in the whole body of male rats $1 \mathrm{hr}, 6 \mathrm{hr}$ and $24 \mathrm{hr}$ after single oral administration of ${ }^{14} \mathrm{C}$-tolclofos-methyl at $5 \mathrm{mg} / \mathrm{kg}$.

activity was present in the whole body of rats.

Seven days after single oral administration, 27 tissues of male and female rats were each examined for ${ }^{14} \mathrm{C}$ residues. As shown in Table 4 , the ${ }^{14} \mathrm{C}$ residues were less than $6 \mathrm{ppb}$ tolclofos-methyl equivalents in most of the tissues analyzed, except that hair contained 52 to $60 \mathrm{ppb}$. The ${ }^{14} \mathrm{C}$ residues in hair were not removed by rinsing with methanol.

\section{Excretion}

On single oral administration of ${ }^{14} \mathrm{C}$-tolclo- fos-methyl to both sexes of rats and mice, 74 to $83 \%$ of the administered radioactivity was excreted into urin, feces and expired air within 1 day after treatment, as shown in Table 5. During the 7 days after treatment, approximately 87 to $91 \%$ of the dose was recovered in the excreta. Of this, 65 to $70 \%$ of the dose, 17 to $22 \%$ and 0.3 to $0.7 \%$ was eliminated into urine, feces and expired air, respectively, of both sexes of rats. On the other hand, 82 to $83 \%$ of the dose, 5 to $7 \%$ and 0.6 to $0.9 \%$ was recovered in urine, feces 
Table 5 Cumulative excretion of radiocarbon into the urine, feces and expired air after oral administration of $5 \mathrm{mg} / \mathrm{kg}$ of ${ }^{14} \mathrm{C}$-tolclofos-methyl to rats and mice.

\begin{tabular}{|c|c|c|c|c|c|c|}
\hline \multirow{3}{*}{ Mammals } & \multirow{3}{*}{ Sex } & \multirow{3}{*}{ Excreta } & \multicolumn{4}{|c|}{$\%$ of the administered radiocarbon } \\
\hline & & & \multicolumn{4}{|c|}{ Days after administration } \\
\hline & & & 1 & 2 & 4 & $7 *$ \\
\hline \multirow[t]{8}{*}{ Rats } & \multirow{4}{*}{ Male } & Urine & 66.7 & 69.2 & 69.6 & 69.8 \\
\hline & & Feces & 16.4 & 17.0 & 17.1 & 17.2 \\
\hline & & Expired air & 0.2 & 0.3 & 0.3 & 0.3 \\
\hline & & Total & 83.3 & 86.5 & 87.0 & 87.3 \\
\hline & \multirow[t]{4}{*}{ Female } & Urine & 62.1 & 64.1 & 64.8 & 65.1 \\
\hline & & Feces & 20.5 & 21.5 & 21.7 & 21.9 \\
\hline & & Expired air & 0.6 & 0.7 & 0.7 & 0.7 \\
\hline & & Total & 83.2 & 86.3 & 87.2 & 87.7 \\
\hline \multirow[t]{8}{*}{ Mice } & \multirow[t]{4}{*}{ Male } & Urine & 75.9 & 83.1 & 83.2 & 83.3 \\
\hline & & Feces & 5.8 & 6.6 & 6.7 & 6.7 \\
\hline & & Expired air & 0.7 & 0.9 & 0.9 & 0.9 \\
\hline & & Total & 82.4 & 90.6 & 90.8 & 90.9 \\
\hline & \multirow[t]{4}{*}{ Female } & Urine & 69.3 & 76.7 & 81.0 & 81.5 \\
\hline & & Feces & 4.4 & 4.9 & 5.1 & 5.2 \\
\hline & & Expired air & 0.5 & 0.6 & 0.6 & 0.6 \\
\hline & & Total & 74.2 & 81.2 & 86.7 & 87.3 \\
\hline
\end{tabular}

* The residues remaining in the animal body 7 days after administration were less than $1 \%$ of the dose.

and expired air, respectively, of both sexes of mice. The total ${ }^{14} \mathrm{C}$ residue remaining in the whole body of rats and mice was less than $1 \%$ of the dose at 7 days after administration. In both animals approximately 9 to $13 \%$ of the dose was not recovered.

\section{Metabolites}

Tlc analysis with solvent systems A), B), C), D), E) and F) indicated that at least 13 metabolites were also detected in organosoluble extracts of urine and feces from mice, and 14 metabolites were found in the extracts of urine and feces from rats. All of the 13 metabolites found in male mice were detected in the excreta of male rats, although there were differences in the amounts of these metabolites between the two animals. Also, $t l c$ analysis of the metabolites revealed that no significant differences in the nature and amounts of metabolites were found between male and female of both animal species. The data on male animals are listed in Table 6. Among 14 metabolites detected on $t l c$, 13 metabolites, from S1 to S14 except S8, were tentatively identified by $t l c$ cochromatography with the authentic standards by increasing numerical orders as $\mathrm{TM}, \mathrm{Ph}-\mathrm{CH}_{3}$, $\mathrm{TM}-\mathrm{CH}_{2} \mathrm{OH}, \mathrm{Ph}-\mathrm{CH}_{2} \mathrm{OH}, \mathrm{TM}-\mathrm{COOH}, \mathrm{Ph}-$ $\mathrm{COOH}$, TMO-COOH, DM-TM, DM-TM$\mathrm{COOH}, \quad \mathrm{DM}-\mathrm{TM}-\mathrm{CH}_{2} \mathrm{OH}, \quad \mathrm{DM}-\mathrm{TMO}-\mathrm{COOH}$ and DM-TMO- $\mathrm{CH}_{2} \mathrm{OH}$, respectively. In addition, the NMR and MS spectra of S6 coincided well with those of the authentic $\mathrm{Ph}$ $\mathrm{COOH}$. The NMR spectrum $(100 \mathrm{MHz})$ in $\mathrm{CD}_{3} \mathrm{OD}$ of $\mathrm{S} 8$ indicated the presence of two methylene protons $\left(\delta^{\mathrm{TMS}}=3.92 \mathrm{ppm}, \mathrm{s}\right)$ and two aromatic protons $\left(\delta^{\mathrm{TMS}}=7.93 \mathrm{ppm}, \mathrm{s}\right)$. The metabolite S8 was methylated by reaction with diazomethane for $12 \mathrm{hr}$ at room temperature to give one product, which was purified by preparative $t l c$ in solvent systems A) and B) ( $R f=0.40$ and 0.67 , respectively). The methylated S8 gave NMR $(100 \mathrm{MHz})$ spectral signals in $\mathrm{CDCl}_{3}$ at $\delta^{\mathrm{TMS}}=3.82 \mathrm{ppm}$ (s, $\left.\mathrm{COOCH}_{3}\right), 3.95 \mathrm{ppm}\left(\mathrm{s}, \mathrm{OC}_{3}\right), 4.22 \mathrm{ppm}$ (d, $\left.J=5 \mathrm{~Hz}, \mathrm{NCH}_{3}\right), 6.50$ ppm (broad s, NH) and $7.76 \mathrm{ppm}$ (s, aromatic $2 \underline{\mathrm{H}}$ ). The EI-MS fragments of the methylated S8 appeared at $m / e \quad 293 \quad(\mathrm{M}+2), \quad 291 \quad(\mathrm{M}), \quad 234 \quad(\mathrm{M}+2$ 
Table 6 Relative amounts of tolclofos-methyl metabolites excreted into urine and feces during $24 \mathrm{hr}$ after oral administration of ${ }^{14} \mathrm{C}$-tolclofos-methyl to male rats and mice.

\begin{tabular}{|c|c|c|c|c|c|}
\hline & \multirow{3}{*}{ Metabolite } & \multicolumn{4}{|c|}{ Amounts ( $\%$ of the administered radiocarbon) } \\
\hline & & \multicolumn{2}{|c|}{ Rats } & \multicolumn{2}{|c|}{ Mice } \\
\hline & & Urine & Feces & Urine & Feces \\
\hline S 1 & $\mathrm{TM}$ & nd** & 5.0 & nd & 1.3 \\
\hline S 2 & $\mathrm{Ph}-\mathrm{CH}_{3}$ & 7.9 & 3.5 & 7.9 & 0.8 \\
\hline S 3 & $\mathrm{TM}-\mathrm{CH}_{2} \mathrm{OH}$ & nd & trace & nd & 0.1 \\
\hline S 4 & $\mathrm{Ph}-\mathrm{CH}_{2} \mathrm{OH}$ & 3.0 & 1.6 & 2.5 & 0.2 \\
\hline S 5 & TM-COOH & 3.3 & 0.7 & 3.0 & 1.0 \\
\hline S 6 & $\mathrm{Ph}-\mathrm{COOH}$ & 26.1 & 3.2 & 10.4 & 1.2 \\
\hline S 7 & TMO-COOH & 7.8 & 0.7 & 9.9 & 0.7 \\
\hline S 8 & $\mathrm{Ph}$-CO-glycine & trace*** & nd & 13.2 & nd \\
\hline S 9 & DM-TM & 4.3 & trace & 0.9 & trace \\
\hline $\mathrm{S} 10$ & $\mathrm{DM}-\mathrm{TM}-\mathrm{COOH}$ & 3.3 & 0.3 & nd & nd \\
\hline S11 & DM-TM- $\mathrm{CH}_{2} \mathrm{OH}$ & 1.3 & 0.2 & 3.8 & 0.1 \\
\hline $\mathrm{S} 12$ & DM-TMO & 1.9 & 0.3 & 3.3 & 0.1 \\
\hline $\mathrm{S} 13$ & DM-TMO-COOH & 5.5 & 0.3 & 12.0 & 0.1 \\
\hline S14 & DM-TM- $\mathrm{CH}_{2} \mathrm{OH}$ & 0.4 & trace & 4.0 & trace \\
\hline \multicolumn{2}{|c|}{ Others* } & 1.9 & 0.6 & 5.0 & 0.2 \\
\hline \multicolumn{2}{|c|}{ Total } & 66.7 & 16.4 & 75.9 & 5.8 \\
\hline
\end{tabular}

* methanol-insoluble ${ }^{14} \mathrm{C},{ }^{*}$ nd: not detected, $* * *$ trace: less than $0.1 \%$.

$\left.\mathrm{COOCH}_{3}\right), \quad 232\left(\mathrm{M}-\mathrm{COOCH}_{3}\right), \quad 205 \quad(\mathrm{M}+2-$ $\left.\mathrm{NHCH}_{2} \mathrm{COOCH}_{3}\right)$ and 203 (M- $\mathrm{NHCH}_{2}-$ $\left.\mathrm{COOCH}_{3}\right)$. Based on these data, S8 was identified as 3,5-dichloro-4-hydroxybenzyl glycine, $\mathrm{Ph}-\mathrm{CO}$-glycine. $\mathrm{Ph}-\mathrm{CO}$-glycine was one of the major metabolites in mice, but a minor product in rats. The metabolite DM$\mathrm{TM}-\mathrm{COOH}$ (S10) was found in rats, but not in mice. The 12 other metabolites were formed in both animal species, although these amounts differed in the two animals. Large amounts of metabolites S6, S2, S7, S13, S1 and $\mathrm{S} 4$ were found in rats, whereas, metabolites S8, S6, S13, S7 and S2 were formed to large extents in mice.

Figure 2 shows the proposed metabolic pathways for ${ }^{14} \mathrm{C}$-tolclofos-methyl in rats and mice.

\section{DISCUSSION}

Upon single oral administration of $5 \mathrm{mg} /$ $\mathrm{kg}$ of ${ }^{14} \mathrm{C}$-tolclofos-methyl to male rats, the radiocarbon was readily absorbed and distributed mainly into stomach, intestines, liver and kidney, as shown by whole-body autoradiography. ${ }^{14} \mathrm{C}$-Tolclofos-methyl was rapid-

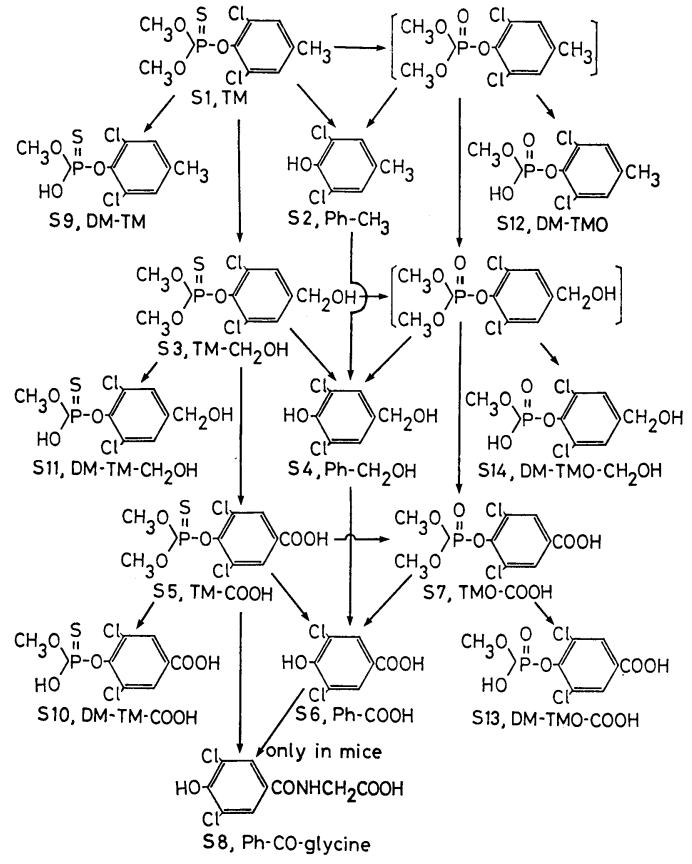

Fig. 2 Proposed metabolic pathways for tolclofosmethyl in rats and mice. 
ly metabolized in rats and mice of both sexes and the metabolites were excreted mainly into the urine and feces, and also into the expired air to a minor extent. Total recovery of the radiocarbon was about 87 to $91 \%$. However, the ${ }^{14} \mathrm{C}$ residue in most of the tissues were very low, and the total ${ }^{14} \mathrm{C}$ residue in the whole animal body was less than $1 \%$ of the administered radiocarbon 7 days after treatment. Therefore, it is presumed that a part of tolclofos-methyl and/or metabolites may disappear from the excreta by evaporation during the collection of urine and feces, since tolclofos-methyl and $\mathrm{Ph}-\mathrm{CH}_{3}$ have high vapor pressure. ${ }^{3,4)}$

As expected from the results of many studies on metabolism of organophosphorus insecticides in mammals, tolclofos-methyl underwent oxidation of the $P=S$ group to $P=O$ group, oxidation at the 4-methyl group, and cleavage of the $P-O$-aryl and $P-O$-methyl linkages. In general, the oxidation reactions and cleavage of the $P-O$-aryl linkage of the $P=S$ compound are mediated by liver microsomal oxidases, so-called mixed function oxidases. The cleavage of $P-O$-methyl (alkyl) and/or $P-O$-aryl linkage of both $P=S$ and $P=$ $O$ compounds is catalyzed by GSH S-transferases. Also, the $P-O$-aryl linkage of $P=O$ compounds is hydrolyzed by A-esterase. It was reported that liver microsomal oxidase and GSH S-transferase activities were higher in mouse liver than in rat liver, whereas Aesterase activity was higher in rat liver than in mouse liver, when fenitrothion and fenitrooxon were used as substrates. ${ }^{14)}$ In rats and mice administered tolclofos-methyl, cleavage of the $P-O$-aryl linkage occurred to a greater extent in rats than in mice. In contrast, oxidations of the $P=S$ group to the $P=O$ group and the 4-methyl group, and desmethylation of the $\mathrm{P}-\mathrm{O}$-methyl group were more predominant in mice than in rats. $\mathrm{Ph}-\mathrm{COOH}$ was the major metabolite with both animal species; however, its conjugation with glycine occurred in mice to a larger extent, but to a trace extent in rats.

When metabolism of tolclofos-methyl in rats and mice is compared with that of fenitrothion which has 3-methyl-4-nitrophenyl group and $O, O$-dimethyl phosphorothioate group in the molecule, there were marked differences in the relative amounts of metabolites. The oxidation of the 4-methyl group constitutes a major metabolic reaction with tolclofos-methyl, but a minor with fenitrothion. ${ }^{12)}$ On the other hand, desmethylation products accounted for 35 to $43 \%$ of the dose with fenitrothion, but only 18 to $24 \%$ of the dose with tolclofos-methyl. ${ }^{12}$ ) The cleavage of $P-O$-aryl linkage was one of major metabolic pathways with both fenitrothion and tolclofos-methyl. The phenolic metabolites produced from fenitrothion were subsequently conjugated to form the majority of the corresponding glucuronides and sulfates. $^{12)}$ On the other hand, the phenolic metabolites from tolclofos-methyl were mostly present as free form. It appears that the pholic $\mathrm{OH}$ group of 2,6-dichlorophenols may have steric hinderance related to 2 orthochlorine atoms, which may restrict conjugation reactions with uridine diphosphate glucuronic acid and/or 3'-phosphoadenosine$5^{\prime}$-phospho sulfate.

\section{ACKNOWLEDGEMENTS}

The authors wish to express their thanks to Mr. Y. Misaki and Miss I. Furukawa for their skilled technical assistance in carrying out this work.

\section{REFERENCES}

1) Y. Kawase, T. Kato, T. Ohishi \& S. Yamamoto: J. Pesticide Sci., submitted

2) H. Koda, T. Kadota \& J. Miyamoto: unpublished observations

3) N. Mikami, K. Hayashi \& J. Miyamoto: J. Pesticide Sci., submitted

4) N. Mikami, J. Yoshimura \& J. Miyamoto: J. Pesticide Sci., submitted

5) T. Yoshitake, H. Kanamaru, F. Shono \& I. Nakatsuka: J. Labelled Compd. Radiopharm. 16, 477 (1980)

6) H. Biltz: Chem. Ber. 37, 4031 (1904)

7) Y. Nishizawa, M. Nakagawa, Y. Suzuki, H. Sakamoto \& T. Mizutani: Agric. Biol. Chem. 25, 597 (1961)

8) G. M. Steinberg: J. Org. Chem. 15, 637 (1950)

9) H. I. Schlesinger \& H. C. Brown: J. Am. Chem. Soc. 75, 215 (1953)

10) J. W. Ladbury \& C. F. Cullis: Chem. Revs. 58, 403 (1958)

11) M. Sasaki: unpublished observations

12) J. Miyamoto, K. Mihara \& S. Hosokawa: J. 
Pesticide Sci. 1, 9 (1976)

13) S. Ullberg: Acta Radiol. Suppl. 118, 1 (1954)

14) K. Mihara, Y. Misaki \& J. Miyamoto: J. Pesticide Sci. 4, 175 (1979)

\section{要 約}

トルクロホスメチルのラットおよびマウスに おける代謝

三原一優，大川秀郎，宮本純之 ${ }^{14} C-4$-メチル標識トルクロホスメチル（リゾレック ス®)を $5 \mathrm{mg} / \mathrm{kg}$ の割合でラット扎よびマウスの雌雄ラ ットにそれぞれ 1 回経口投与すると，投与した ${ }^{14} \mathrm{C}$ の
87 91\%が 1 週間以内に䔬尿中に排泄された. 投与. 1 週間後，体内の ${ }^{14} \mathrm{C}$ 残存量は投与量の $1 \%$ 以下であり， しかも各種組織における残存量は $0.06 \mathrm{ppm}$ 以下であり， 組織内に ${ }^{14} \mathrm{C}$ が蓄積する傾向は認められなかった。両動 物の排泄物中には少なくとも 14 個の代謝物が見いださ れ，そのうち 13 個は両動物で共通したものであった。 トルクロホスメチルは打もに $\mathrm{P}=\mathrm{S}$ 基の $\mathrm{P}=\mathrm{O}$ 基への酸化 的脱硫化，4-メチル基の酸化および $\mathrm{P}-\mathrm{O}-$ アリル結合と P-O-メチル結合の開裂を経て代謝され，主要代謝物は 3,5-ジクロロ-4-ヒドロキシ安息香酸であった。この代 謝物はラットではほとんど遊離で存在したが，マウスで は $55 \%$ がグリシン抱合をうけていた。 